\title{
The impact of work-related risk factors on the development of neck and upper limb pain among low wage hotel housekeepers in Gondar town, Northwest Ethiopia: institution-based cross-sectional study
}

\author{
Sintayehu Daba Wami* (D, Awrajaw Dessie and Daniel Haile Chercos
}

\begin{abstract}
Background: Musculoskeletal disorders are a major source of disability accounting for considerable economic loss globally. Studies showed that housekeepers suffer from exposure to many high-risk factors for neck and upper limb musculoskeletal disorders. In Ethiopia, little is known and the information is limited in scope about the magnitude of the problem among hotel housekeepers. Therefore, this study aimed to determine the magnitude of the neck and upper limb musculoskeletal disorders and identify the associated risk factors among hotel housekeepers.

Methods: Institution-based cross-sectional study design was employed from March 1 to May 20, 2017. Systematic random sampling was used to select 422 study participants among the Gondar town hotels, Ethiopia. The standardized Nordic questionnaire for the analysis of musculoskeletal symptoms was used to measure the neck and upper limb musculoskeletal disorders. Bivariate and multivariable binary logistic regression analyses were performed using SPSS version 20. The significance level was obtained at $95 \% \mathrm{Cl}$ and $p$ value $\leq 0.05$.

Results: The overall magnitude of a self-reported neck and upper limb musculoskeletal disorders among hotel housekeepers in the last 12 months was $62.8 \%(95 \% \mathrm{Cl} 58.3,67.8)$. The main body areas of concern were neck pain (50.7\%), shoulder pain (54\%), elbow/forearm (47.2\%), and hand/wrist (45.5\%). Age, rest break taken, repetitive movement, reaching/overstretching, organization concern for health and safety, and job satisfaction were the risk factors significantly associated with neck and upper limb musculoskeletal disorders.

Conclusions: A higher proportion of hotel housekeepers were found to be affected by neck and upper limb musculoskeletal disorders in Gondar town. Repetitive movement and reaching/overstretching were strongly associated risk factors with neck and upper limb musculoskeletal disorders. Therefore, ergonomic, organizational and personal measures, which focus on minimizing repetitive movement and awkward working position and facilitating rest break with exercise, are important to tackle neck and upper limb musculoskeletal disorders among hotel housekeepers.
\end{abstract}

Keywords: Neck pain, Upper limb pain, Musculoskeletal disorders, Hotel housekeepers, Gondar, Ethiopia

\footnotetext{
* Correspondence: sintayehudaba2004@gmail.com

Department of Environmental and Occupational Health and Safety, Institute

of Public Health, University of Gondar, Gondar, Ethiopia
}

(c) The Author(s). 2019 Open Access This article is distributed under the terms of the Creative Commons Attribution 4.0 International License (http://creativecommons.org/licenses/by/4.0/), which permits unrestricted use, distribution, and reproduction in any medium, provided you give appropriate credit to the original author(s) and the source, provide a link to the Creative Commons license, and indicate if changes were made. The Creative Commons Public Domain Dedication waiver (http://creativecommons.org/publicdomain/zero/1.0/) applies to the data made available in this article, unless otherwise stated. 


\section{Background}

Neck and upper limb musculoskeletal disorders are the most common health problem in the workplace accounting for considerable economic loss [1-7]. Musculoskeletal disorders (MSDs) are impairments of body structures such as tendons, muscles, joints, ligaments, nerves, bones, or a localized blood circulation system caused or aggravated by the work [7-10]. While neck and upper limb musculoskeletal disorders are defined as conditions which affect the soft tissues (tendons, muscles, joints, ligaments, and nerves) of the neck and upper limbs [9, 11-13].

Housekeeping is a physically demanding job that includes many tasks and housekeepers suffer from exposure to many high-risk factors for neck and upper limb MSDs [14]. Many of the tasks are repetitive in nature such as bed making, buffing and vacuuming, emptying garbage, tidying, dusting, and cleaning floors. Moreover, housekeepers are engaged in push-pull task that result biomechanical strain factors such as joint torque, compressive and shear forces, and their influencing variables like specific muscle activity, body positioning, the direction of exertion, and workspace environment $[13,15]$.

Studies conducted across countries showed a high magnitude of the neck and upper limb MSDs among housekeepers [13, 16-18]. Despite the high magnitude of the problem, little is known and the information is limited in scope about the magnitude and associated factors of neck and upper limb MSDs among hotel housekeepers in Africa [16].

Adverse events due to neck and upper limb MSDs represent a major source of disability globally and have a significant socio-economic impact $[2,19,20]$. Moreover, employees with neck and upper limb MSDs experience physical and mental suffering and temporary or permanent limitations in their professional activities [21]. Many factors can be associated with neck and upper limb MSDs. Different studies conducted showed that repeated lifting of heavy objects, prolonged bending of the neck, overstretching, low little job control, and low supervisor support are significantly associated factors with neck and upper limb MSDs [16, 22, 23]. Furthermore, Neck and upper limb MSDs were not only associated with physical workplace factors but also with psychosocial factors like stress, lack or poor communication, and work ambiguity [24-26].

There is strong evidence that technical ergonomic measures and several kinds of interventions including organizational and personal measures can reduce the occurrence of neck and upper MSDs [7, 27-32]. However, in most African countries including Ethiopia, little is known about the risk factors associated with neck and upper limb MSDs among hotel housekeepers. There is also little empirical evidence about the magnitude of the problem in Ethiopia.
Therefore, this study aimed to determine the magnitude of neck and upper limb MSDs and identify the associated risk factors among hotel housekeepers.

\section{Methods}

Aim, study design, and setting

The overall aim of this study was to assess the magnitude of neck and upper limb MSDs and associated risk factors among hotel housekeepers in Gondar town, Northwest Ethiopia.

Institution-based cross-sectional study design was employed from March 1 to May 20, 2017. The study was conducted in Gondar town hotels, Northwest Ethiopia. Gondar town is one of a tourist destination city in Amhara Regional State, which is located in the northwestern part of Ethiopia, about $750 \mathrm{~km}$ from the capital city, Addis Ababa. A hotel industry was one of the known industries in the town. There are more than 120 hotels in the town, and housekeepers are the largest workforce in this industry.

\section{Source and study population}

All hotel housekeepers in Gondar town were the source population. Those housekeepers who had worked at least for 12 months were included in this study. While hotel housekeepers with spinal deformities or accidents affecting the musculoskeletal system were excluded from the study.

\section{Sample size determination and sampling procedures}

The sample size was determined by using a single population proportion formula, assuming a $50 \%$ proportion of neck and upper limb MSDs, 5\% margin of error and 95\% confidence interval. By considering possible non-response during the data collection period a $10 \%$ non-response rate was added on the final sample size. Finally, a total of 422 study participants were included in the study. A systematic random sampling technique was used to select the study participants among the hotels.

\section{Data collection tool and procedures}

The data was collected through face-to-face interview data collection technique.

A standardized Nordic questionnaire for the analysis of musculoskeletal symptoms was used to measure the outcome variable, neck, and upper limb MSDs. The questionnaire was designed to assess musculoskeletal trouble occur in a given population with consideration of in which parts of the body they are localized. The reliability of the questionnaire has been shown to be acceptable [33]. Moreover, socio-demographic, personal, and work environment characteristics of the participants were also collected. 
The questionnaire was originally in the English version, and it was translated to Amharic local language and back to English by another translator to check the consistency of message from the question. The translation was then reviewed by professional experts. Prior to the commencement of actual data collection, the questionnaire was pretested in $42(10 \%)$ of study subject in Woreta town hotel housekeepers and necessary modification was made on the tool. Six Bachelor of Science graduate of Environmental and Occupational health and safety' data collectors with three supervisors were assigned for the data collection.

\section{Operational definitions}

\section{Neck trouble}

Musculoskeletal symptoms in the neck were defined by aches, pain, or discomfort during the 12 months preceding completion of the questionnaire.

\section{Upper limb/extremity musculoskeletal disorders}

Musculoskeletal symptoms experienced in the upper limb (shoulders, elbows, hands, or wrists) irrespective of neck pain were defined by aches, pain, or discomfort in the past 12 months were also used as an outcome measure.

\section{Body mass index}

Weight in kilograms divided by the square of the height in meters $\left(\mathrm{kg} / \mathrm{m}^{2}\right)$.

$$
\begin{aligned}
& \text { Underweight }=\mathrm{BMI}<18.50 \\
& \text { Normal range }=\mathrm{BMI} \text { b } / \mathrm{n} 18.50-24.99 \\
& \text { Overweight }=\mathrm{BMI} \mathrm{b} / \mathrm{n} 25.00-29.99 \\
& \text { Obese }=\mathrm{BMI} \geq 30.00
\end{aligned}
$$

\section{Satisfaction}

The employee was considered satisfied with a job when his/her sum of generic job satisfaction scale score was 32 or above [34].

\section{Data management and analysis}

Data was checked, edited, coded, and entered to Epi-info version 7.00 and exported to Statistical Package for Social Science (SPSS) version 20 for further analysis.

A chi-square test was conducted to see the association of different factors with the magnitude of neck and upper limb MSDs. A binary logistic regression model was fitted to identify factors associated with neck and upper limb MSDs. Neck and upper limb MSDs were regressed against the socio-demographic, personal, and work environment factors separately. Before fitting the binary logistic regression model, first the goodness of model fit test was checked by the Hosmer-Lemeshow test, and the assumption was satisfied ( $p$ value $>0.05$ ).
Bivariate binary logistic regression analysis was performed and variable with $p$ value $<0.20$ was exported to multivariable binary logistic regression analysis. The significance level was obtained at $95 \% \mathrm{CI}$ and $p$ value $\leq 0.05$. The adjusted odds ratio was used to determine the strength of association.

\section{Data quality control}

During the collection of data, each completed questionnaire was checked for consistency and completeness by supervisors. Throughout the course of the data collection, data collectors were supervised at each site, regular meetings were held between the data collectors and the principal investigator. Ten percent of data was double entered to check error during data entry.

\section{Results}

All 422 completed and valid questionnaires were returned and considered for the analysis, which gives a response rate of $100 \%$.

\section{Socio-demographic and personal characteristics of the study participants}

From the total respondents, majority 388 (91.9\%) were females. The mean $( \pm S D)$ age of the respondents was $26.71 \pm 4.9$ years and the age of the study participants ranged from 20 to 40 years. Almost all 397 (94.1\%) of respondents do not perform physical activity/exercises and $64(15.2 \%)$ of participants were overweight (Table 1).

\section{Working condition of respondents}

Among the study participants, 71 (16.8\%) of respondents were working for more than $8 \mathrm{~h}$ per day and only 90 (21.3\%) of participants took more than 45 min rest break per day excluding lunch break. More than half, 220 (52.1\%) of the respondent's job involve repetitive movements and 248 (58.8\%) of the study participants were not satisfied with their current job. More than two third, 307 (72.7\%) of respondents' mentioned that their organizations do not have a concern for the health and safety of the workers (Table 2).

\section{The magnitude of neck and upper limb musculoskeletal disorders}

The finding of this study revealed that the overall magnitude of self-reported neck and upper limb MSDs among hotel housekeepers was $62.8 \%$ (95\% CI 58.3, 67.8). The main body areas of concern were neck pain $(50.7 \%)$, shoulder pain (54\%), elbow/forearm (47.2\%), and hand/ wrist (45.5\%). Moreover, $58.2 \%$ of respondents were prevented from doing their normal work because of the neck and upper limb disorders from 1 to more than 30 days. Furthermore, the length of time they had neck and upper limb pain also ranges from 1 to more than 30 days. 
Table 1 Socio-demographic and personal characteristics of the study participants, Northwest Ethiopia, $2017(n=422)$

\begin{tabular}{|c|c|c|}
\hline Variables & Frequency $(n)$ & Percent (\%) \\
\hline \multicolumn{3}{|l|}{ Sex } \\
\hline Female & 388 & 91.9 \\
\hline Male & 34 & 8.1 \\
\hline \multicolumn{3}{|l|}{ Age (years) } \\
\hline$\leq 24$ & 194 & 46 \\
\hline $25-29$ & 100 & 23.7 \\
\hline$>29$ & 128 & 30.3 \\
\hline \multicolumn{3}{|l|}{ Marital status } \\
\hline Single & 206 & 48.8 \\
\hline Married & 179 & 42.4 \\
\hline Divorced/widowed & 37 & 8.8 \\
\hline \multicolumn{3}{|l|}{ Educational status } \\
\hline Illiterate & 155 & 36.7 \\
\hline Primary school & 240 & 56.9 \\
\hline Secondary school and above & 27 & 6.4 \\
\hline \multicolumn{3}{|l|}{ Employment pattern } \\
\hline Permanent & 378 & 89.6 \\
\hline Temporary & 44 & 10.4 \\
\hline \multicolumn{3}{|l|}{$\begin{array}{l}\text { Specific work experience in this } \\
\text { work area }\end{array}$} \\
\hline $1-2$ years & 291 & 69 \\
\hline$>2$ years & 131 & 31 \\
\hline \multicolumn{3}{|l|}{ Monthly salary (ETB) } \\
\hline$\leq 500$ & 96 & 22.7 \\
\hline $501-1000$ & 267 & 63.3 \\
\hline$>1000$ & 59 & 14 \\
\hline \multicolumn{3}{|l|}{ Body mass index (BMI) } \\
\hline Underweight & 71 & 16.8 \\
\hline Normal weight & 277 & 65.6 \\
\hline Over weight and & 64 & 15.2 \\
\hline Obese & 10 & 2.4 \\
\hline \multicolumn{3}{|l|}{ None work physical activity } \\
\hline No & 397 & 94.1 \\
\hline Yes & 25 & 5.9 \\
\hline \multicolumn{3}{|l|}{ Smoking behavior } \\
\hline None & 417 & 98.8 \\
\hline Past smoker & 3 & 0.7 \\
\hline Current & 2 & 0.5 \\
\hline \multicolumn{3}{|l|}{ Alcohol drinking } \\
\hline No & 314 & 74.4 \\
\hline Yes & 108 & 25.6 \\
\hline
\end{tabular}

ETB Ethiopian birr
Table 2 Working conditions of the study participants, Northwest Ethiopia, $2017(n=422)$

\begin{tabular}{|c|c|c|}
\hline Variables & Frequency $(n)$ & Percent (\%) \\
\hline \multicolumn{3}{|l|}{ Hours worked per day } \\
\hline$\leq 8 \mathrm{~h}$ & 351 & 83.2 \\
\hline$>8 \mathrm{~h}$ & 71 & 16.8 \\
\hline \multicolumn{3}{|l|}{$\begin{array}{l}\text { Rest break taken per day } \\
\text { (excluding lunch break) }\end{array}$} \\
\hline$<30 \min$ & 107 & 25.4 \\
\hline $30-45 \min$ & 225 & 53.3 \\
\hline$>45 \min$ & 90 & 21.3 \\
\hline \multicolumn{3}{|l|}{ The job requires repetitive work } \\
\hline No & 202 & 47.9 \\
\hline Yes & 220 & 52.1 \\
\hline \multicolumn{3}{|l|}{$\begin{array}{l}\text { The job requires reaching/ } \\
\text { overstretching }\end{array}$} \\
\hline No & 201 & 47.6 \\
\hline Yes & 221 & 52.4 \\
\hline \multicolumn{3}{|l|}{ The job requires bending } \\
\hline No & 204 & 48.3 \\
\hline Yes & 218 & 51.7 \\
\hline \multicolumn{3}{|l|}{ Satisfaction } \\
\hline No & 248 & 58.8 \\
\hline Yes & 174 & 41.2 \\
\hline \multicolumn{3}{|l|}{ Training } \\
\hline No & 323 & 76.5 \\
\hline Yes & 99 & 23.5 \\
\hline \multicolumn{3}{|l|}{$\begin{array}{l}\text { Manager concern for health } \\
\text { and safety }\end{array}$} \\
\hline Disagree/strongly disagree & 307 & 72.7 \\
\hline Neutral & 93 & 22 \\
\hline Agree/strongly agree & 22 & 5.2 \\
\hline
\end{tabular}

Factors associated with neck and upper limb pain The multivariable binary logistic regression showed that rest break taken, repetitive movement, reaching/overstretching, and satisfaction had statistically significant association with neck pain at $p$ value $<0.05$ (Table 3 ). While age, repetitive movement, overstretching/reaching, satisfaction, and organization concern for health and safety had statistically significant association with upper limb pain at $p$ value $<0.05$ (Table 4).

\section{Neck pain}

Rest break taken was positively associated with neck pain. Respondents who had taken more than 45 min rest period per day had $71 \%$ less likely odds of having neck pain when compared to participants who had taken less than $30 \mathrm{~min}$ rest period per day $(\mathrm{AOR}=0.29,95 \% \mathrm{CI}$ $0.13,0.63)$. Moreover, respondents whose job require 
Table 3 Bivariate and multivariable binary logistic regression analysis of factors associated with neck trouble among hotel housekeepers, Northwest Ethiopia, $2017(n=422)$

\begin{tabular}{|c|c|c|c|c|}
\hline \multirow[t]{2}{*}{ Variables } & \multicolumn{2}{|c|}{ Neck pain } & \multirow[t]{2}{*}{$\operatorname{COR}(95 \% \mathrm{Cl})$} & \multirow[t]{2}{*}{ AOR $(95 \% \mathrm{Cl})$} \\
\hline & No & Yes & & \\
\hline \multicolumn{5}{|l|}{ Sex } \\
\hline Male & 26 & 8 & 1.00 & 1.00 \\
\hline Female & 182 & 206 & $3.68(1.62,8.33)^{*}$ & $2.1(0.82,5.42)$ \\
\hline \multicolumn{5}{|l|}{ Age (years) } \\
\hline$\leq 24$ & 102 & 92 & 1.00 & 1.00 \\
\hline $25-29$ & 45 & 55 & $1.36(0.84,2.2)$ & $1.32(0.72,2.43)$ \\
\hline$>29$ & 61 & 67 & $1.22(0.78,1.9)$ & $0.9(0.5,1.59)$ \\
\hline \multicolumn{5}{|l|}{ Educational status } \\
\hline Illiterate & 84 & 71 & 1.00 & 1.00 \\
\hline Primary school & 109 & 131 & $1.42(0.95,2.13)$ & $1.19(0.73,1.96)$ \\
\hline $\begin{array}{l}\text { Secondary school } \\
\text { and above }\end{array}$ & 15 & 12 & $0.95(0.42,2.15)$ & $0.76(0.27,2.12)$ \\
\hline \multicolumn{5}{|c|}{ Specific Work experience in this work area } \\
\hline $1-2$ years & 151 & 140 & 1.00 & 1.00 \\
\hline$>2$ years & 57 & 74 & $1.4(0.93,2.12)$ & $1.06(0.64,1.77)$ \\
\hline \multicolumn{5}{|l|}{ Body mass index (BMI) } \\
\hline Under weight & 31 & 40 & 1.00 & 1.00 \\
\hline Normal weight & 145 & 132 & $0.71(0.42,1.19)$ & $1.14(0.0 .59,2.19)$ \\
\hline Over weight and obese & 32 & 42 & $1.02(0.53,1.96)$ & $1.62(0.71,3.67)$ \\
\hline \multicolumn{5}{|c|}{ Rest break taken per day (excluding lunch break) } \\
\hline$<30 \min$ & 37 & 70 & 1.00 & 1.00 \\
\hline $30-45 \min$ & 104 & 121 & $0.62(0.38,0.99)^{*}$ & $0.71(0.39,1.26)$ \\
\hline$>45 \min$ & 67 & 23 & $0.18(0.1,0.337)^{* *}$ & $0.29(0.13,0.63)^{*}$ \\
\hline \multicolumn{5}{|l|}{ The job requires repetitive work } \\
\hline No & 146 & 56 & 1.00 & 1.00 \\
\hline Yes & 62 & 158 & $6.6(4.34,10.17)^{* *}$ & $1.98(1.01,3.87)^{*}$ \\
\hline \multicolumn{5}{|c|}{ The job requires reaching/overstretching } \\
\hline No & 149 & 52 & 1.00 & 1.00 \\
\hline Yes & 59 & 162 & $7.87(5.1,12.15)^{* *}$ & $3.72(1.81,7.66)^{* *}$ \\
\hline \multicolumn{5}{|l|}{ The job requires bending } \\
\hline No & 135 & 69 & 1.00 & 1.00 \\
\hline Yes & 73 & 145 & $3.89(2.59,5.82)^{* *}$ & $0.64(0.31,1.29)$ \\
\hline \multicolumn{5}{|l|}{ Satisfaction } \\
\hline No & 82 & 166 & 1.00 & 1.00 \\
\hline Yes & 126 & 48 & $0.19(0.12,0.29)^{* *}$ & $0.46(0.27,0.77)^{*}$ \\
\hline \multicolumn{5}{|l|}{ Training } \\
\hline No & 140 & 183 & 1.00 & 1.00 \\
\hline Yes & 68 & 31 & $0.35(0.22,0.56)^{* *}$ & $0.57(0.31,1.04)$ \\
\hline \multicolumn{5}{|c|}{ Manager concern for health and safety } \\
\hline Disagree/strongly disagree & 154 & 153 & 1.00 & 1.00 \\
\hline Neutral & 36 & 57 & $1.59(0.99,2.56)$ & $0.82(0.45,1.50)$ \\
\hline Agree/strongly agree & 18 & 4 & $0.22(0.07,0.68)^{*}$ & $0.31(0.08,1.17)$ \\
\hline
\end{tabular}


Table 4 Bivariate and multivariable binary logistic regression analysis of factors associated with upper limbs pain among hotel housekeepers, Northwest Ethiopia, $2017(n=422)$

\begin{tabular}{|c|c|c|c|c|}
\hline \multirow[t]{2}{*}{ Variables } & \multicolumn{2}{|c|}{ Upper limb pain } & \multirow[t]{2}{*}{$\operatorname{COR}(95 \% \mathrm{Cl})$} & \multirow[t]{2}{*}{ AOR $(95 \% \mathrm{Cl})$} \\
\hline & No & Yes & & \\
\hline \multicolumn{5}{|l|}{ Sex } \\
\hline Male & 25 & 9 & 1.00 & 1.00 \\
\hline Female & 146 & 242 & $4.6(2.09,10.14)^{* *}$ & $2.64(0.98,7.09)$ \\
\hline \multicolumn{5}{|l|}{ Age (years) } \\
\hline$\leq 24$ & 96 & 98 & 1.00 & 1.00 \\
\hline $25-29$ & 30 & 70 & $2.29(1.37,3.81)^{*}$ & $3.39(1.63,7.07)^{*}$ \\
\hline$>29$ & 45 & 83 & $1.8(1.14,2.86)^{*}$ & $1.56(0.81,2.99)$ \\
\hline \multicolumn{5}{|l|}{ Educational status } \\
\hline Illiterate & 72 & 83 & 1.00 & 1.00 \\
\hline Primary school & 88 & 152 & $1.49(0.99,2.26)$ & $1.15(0.66,2.02)$ \\
\hline Secondary school and above & 11 & 16 & $1.26(0.55,2.89)$ & $0.97(0.31,3.11)$ \\
\hline \multicolumn{5}{|c|}{ Specific work experience in this work area } \\
\hline $1-2$ years & 122 & 169 & 1.00 & 1.00 \\
\hline$>2$ years & 49 & 82 & $1.2(0.79,1.84)$ & $0.78(0.43,1.41)$ \\
\hline \multicolumn{5}{|l|}{ Body mass index (BMI) } \\
\hline Under weight & 26 & 45 & 1.00 & 1.00 \\
\hline Normal weight & 118 & 159 & $0.78(0.45,1.33)$ & $1.89(0.0 .88,4.08)$ \\
\hline Over weight and obese & 27 & 47 & $1.01(0.51,1.98)$ & $1.99(0.76,5.20)$ \\
\hline \multicolumn{5}{|c|}{ Rest break taken per day (excluding lunch break) } \\
\hline$<30 \min$ & 31 & 76 & 1.00 & 1.00 \\
\hline $30-45 \mathrm{~min}$ & 89 & 136 & $0.62(0.38,1.02)$ & $0.61(0.31,1.23)$ \\
\hline$>45 \min$ & 51 & 39 & $0.31(0.17,0.56)^{* *}$ & $0.47(0.2,1.14)$ \\
\hline \multicolumn{5}{|l|}{ The job requires repetitive work } \\
\hline No & 138 & 64 & 1.00 & 1.00 \\
\hline Yes & 33 & 187 & $12.22(7.6,19.6)^{* *}$ & $6.44(2.99,13.84)^{* *}$ \\
\hline \multicolumn{5}{|c|}{ The job requires reaching/overstretching } \\
\hline No & 134 & 67 & 1.00 & 1.00 \\
\hline Yes & 37 & 184 & $9.9(6.28,15.74)^{* *}$ & $3.33(1.48,7.51)^{*}$ \\
\hline \multicolumn{5}{|l|}{ The job requires bending } \\
\hline No & 117 & 87 & 1.00 & 1.00 \\
\hline Yes & 54 & 164 & $4.08(2.7,6.18)^{* *}$ & $0.45(0.19,1.05)$ \\
\hline \multicolumn{5}{|l|}{ Satisfaction } \\
\hline No & 50 & 198 & 1.00 & 1.00 \\
\hline Yes & 121 & 53 & $0.11(0.07,0.17)^{* *}$ & $0.22(0.13,0.38)^{* *}$ \\
\hline \multicolumn{5}{|l|}{ Training } \\
\hline No & 119 & 204 & 1.00 & 1.00 \\
\hline Yes & 52 & 47 & $0.53(0.34,0.83)^{*}$ & $0.78(0.41,1.50)$ \\
\hline \multicolumn{5}{|c|}{ Manager concern for health and safety } \\
\hline Disagree/strongly disagree & 117 & 190 & 1.00 & 1.00 \\
\hline Neutral & 36 & 57 & $0.98(0.61,1.57)$ & $0.35(0.17,0.72)^{*}$ \\
\hline Agree/strongly agree & 18 & 4 & $0.14(0.05,0.41)^{* *}$ & $0.11(0.02,0.60)^{*}$ \\
\hline
\end{tabular}

Gender, sex, and BMI were adjusted covariates

Note: 1:00 $=$ reference, ${ }^{*}=$ variable $p$ value $<0.05,{ }^{* *}=p$ value $\leq 0.001$ 
repetitive movement had almost two times higher odds of developing neck trouble than whose task does not require repetitive movement $(\mathrm{AOR}=1.98,95 \% \mathrm{CI} 1.01,3.87)$. This study showed jobs which require reaching/overstretching were a risk factor for neck trouble. Respondents whose job require reaching/overstretching had 3.72 times higher odds of having neck trouble than those whose task does not require reaching/overstretching $(\mathrm{AOR}=3.72$, 95\% CI $1.81,7.66)$. Moreover, respondents who were satisfied with their current job had $54 \%$ less likely odds of having neck trouble when compared to those who were not satisfied $(\mathrm{AOR}=0.46,95 \% \mathrm{CI} 0.27,0.77)$.

\section{Upper limb pain}

Age was significantly associated with upper limb disorders. Participants with the age group of 25-29 had 3.39 times higher odds of developing upper limb pain when compared to participants with the age $\leq 24(\mathrm{AOR}=3.39$, $95 \%$ CI 1.63, 7.07). Moreover, respondents whose job requires repetitive movement had 6.44 times higher odds of having upper limb pain than whose task does not require repetitive movement $(\mathrm{AOR}=6.44,95 \% \mathrm{CI} 2.99$, 13.84). A job that involves overstretching was significantly associated with upper limb pain. Respondents whose job require reaching/overstretching had 3.33 times higher odds of having upper limb pain when compared to those whose task does not require reaching/ overstretching ( $\mathrm{AOR}=3.33$, 95\% CI 1.48, 7.51). Moreover, respondents who were satisfied with their current job had $78 \%$ less likely odds of developing upper limb pain than those who were not satisfied (AOR $=0.22$, 95\% CI 0.13, 0.38). Furthermore, manager concern for health and safety had a positive association with upper limb pain. Respondents who strongly agree/agree that there was manager concern for health and safety had $89 \%$ less likely odds of having upper limb pain than those who strongly disagree/disagree $(\mathrm{AOR}=0.11,95 \% \mathrm{CI}$ $0.02,0.60)$.

\section{Discussion}

The result of this study revealed that the overall magnitude of a self-reported neck and upper limb trouble among Gondar town hotel housekeepers was 62.8\% (95\% CI 58.3, 67.8). The highest magnitude of MSDs was reported in shoulder body region (54\%); followed by neck pain (50.7\%), elbow/forearm pain (47.2\%), and hand/wrist pain (45.5\%) respectively. This result showed that the magnitude of neck and upper limb MSDs among hotel housekeepers in Gondar town was high. This may be explained as hotel housekeepers in this study perform cleaning, washing, and bed dressing which involves lifting, pulling and carrying a heavy load, working with the arms above shoulder, repetitive movement, and working in a range of awkward posture they are at high risk of developing neck and upper limb MSDs [14]. This result is supported by a study conducted in India which stated that the high magnitude of neck and upper limb MSDs among hotel housekeepers may be related to repetitive work, manual handling, and altered posture [27]. The overall magnitude of neck and upper limb MSDs of this study is lower when compared with the study reported, $77 \%$ musculoskeletal pain among low-income community female homemakers in Lebanon [35]. The possible reason might be due to the difference in the study participants' socio-demographic characteristics, and this study only reported neck and upper limb MSDs while they had reported any musculoskeletal pain in the past 12 months.

However, the magnitude of neck and upper limb MSDs of this study is higher when compared with the study reported $32 \%$ upper extremity MSDs among hotel housekeepers in the USA (16), and the study that showed neck pain (29.9\%), elbow pain (25.4\%), and hand/wrist (22\%) among hotel housekeepers in Orlando [17]. Another similar research reported 33\% neck pain, $23 \%$ shoulder pain and $22 \%$ hand/wrist pain among cleaner in the UK [36]. However, $74 \%$ of cleaners in the later study reported experiencing aches, pains, and discomfort in the last 1 year including back and lower extremity troubles [36]. This difference might be due to the difference in work organization between countries. Those countries might have better work condition, ergonomic design of tools and equipment and organizational concern for health and safety of housekeepers.

Moreover, the magnitude of neck and upper limb MSDs of this study is higher when compared to the study reported, $33.3 \%$ neck pain, $23.3 \%$ shoulder pain, $36.7 \%$ hand/ wrist pain and $8.3 \%$ elbow pain among full time lady servants in Egypt [16], and 42\% shoulder pain, 35\% neck pain, $29 \%$ hand/wrist pain, and 18\% elbow pain among housewives in India [37]. This difference might be due to the difference in the sample size of the studies, socio-demographic characteristics, and organization of the work. Other possible reasons might be due to the prolonged work without the opportunity to rest and tasks carried by hotel housekeepers. In this study, housekeepers' job involves more awkward posture, repetitive movement of the neck and upper extremity, and perform less physical exercise. In addition, there is less concern of organization for health and safety of housekeepers compared with those countries.

The multivariable binary logistic regression showed that there was no significant association observed between sex, body mass index (BMI), physical exercise, and neck and upper limb MSDs. However, different studies reported the presence of gender difference in upper extremity MSDs among the working population in many occupational classes, with female workers having a higher risk [38-40]. This difference might be due 
to the differences in the distribution of male and female workers in occupations with different risks for the neck and upper limb MSDs between countries.

Rest break taken had statistically significant association with neck pain. Respondents who had taken more than $45 \mathrm{~min}$ rest period per day had $71 \%$ less likely odds of having neck pain when compared to participants who had taken less than $30 \mathrm{~min}$ rest period per day. This result may be explained as; when workers take more frequent rest breaks in working day possibility of recovery increased and reduce the incidence of neck pain. This is in line with the European agency of health and safety report which stated that prolonged work without the opportunity to rest and recover from the load is a risk factor for MSDs [41].

This study showed that works which involve a repetitive movement of the neck and upper limb had a statistically significant association with neck and upper limb trouble. Participants whose job require repetitive movement of upper extremities' had higher odds of having neck and upper limb MSDs than those whose task does not require repetitive movement. This finding is in line with the result reported in Egypt [16], the UK [22], Lebanon [35], and the USA [42]. This might be explained as work involving repetitive movements is very tiring because the worker cannot fully recover in the short periods of time between movements, thus neck and upper limb MSDs might develop. Moreover, as repetitive movement involves the same joints and muscle groups, the risk of neck and upper limb MSDs increased.

This study found that jobs which require reaching/ overstretching were a risk factor for neck and upper limb MSDs. Respondents whose job require reaching/ overstretching had almost 3.5 times higher odds of having neck and upper limb MSDs than those whose task does not require reaching/overstretching. This result is in line with the study conducted in Egypt [16], France [24], and Lebanon [35], which reported working in awkward posture including working with hands above shoulder was a risk factor for neck and upper limb MSDs. The possible reason might be hotel housekeepers usually working in uncomfortable working posture or awkward postures represent unnatural positions, deviated from "neutral positions," in which joints are held or moved away from the body's natural position. The closer the joint is to its end of the range of motion, the greater the stress placed on the soft tissues of that joint, such as muscles, nerves, and tendons. When muscles are contracted, the body is subjected to a greater mechanical effort. When working with joint positions of the upper limb outside comfort angle; increase the possibility of upper limb MSDs.

According to this study, hotel housekeepers who were satisfied with their current job were less likely to be affected by neck and upper limb MSDs when compared to those who were not satisfied. This finding is similar to the study conducted in the UK [22] which reported poor job satisfaction was associated with the increased magnitude of neck and upper limb MSDs. This finding is also supported by a study conducted in Quebec [43], which reported cleaners working alone may feel isolated even isolated onwards with others, so this might lead to less satisfaction and increase the risk of MSDs. Other possible explanations might be when they work in a situation with high job satisfaction, a high influence over work-related decisions and get social support they are less likely to develop neck and upper limb MSDs than others [44].

As per this study, age was significantly associated with upper limb disorders. Participants with the age group of 25-29 had 3.39 times higher odds of having upper limb pain when compared to participants with the age $\leq 24$. This finding is in line with the study conducted in Seoul hotel workers [39] and France [24] which reported the risk of developing upper limb MSDs was higher among older age workers than those with younger age. This might be explained as the functional capacity of soft tissues and muscle strength decrease with age the possibility of upper limb MSDs increase. Other possible reasons might be the accumulation of years of exposure to MSDs risk factors among older age increase the magnitude of upper limb MSDs [23].

Furthermore, manager concern for health and safety had a positive association with upper limb MSDs. Respondents who strongly agree/agree that there was manager concern for health and safety had 89\% less likely odds of having upper limb pain than those who strongly disagree/disagree. This might explain how strong support and concern from the manager toward health and safety of hotel housekeepers reduce the risk of upper limb MSDs.

\section{Limitations of the study}

Though this study was able to provide important data on the neck and upper limb pain among hotel housekeepers, several limitations are noted. Not undertaking ergonomic audits of workstations and activities was one of the limitations of the study. In addition, since this study was a questionnaire-based cross-sectional study, the possibility of recall bias could not be ruled out since more serious and recent pains or troubles remembered better than less serious and older one. But we have tried to minimize the effect by honestly explaining the objective and significances of the study to the study participants and by using standardized questionnaire for assessing MSDs. Despite these limitations, we feel the study provide a reasonably accurate assessment of the 
impact of work-related risk factors on the development of neck and upper limb pain among hotel housekeepers.

\section{Conclusions}

A higher proportion of hotel housekeepers were found to be affected by neck and upper limb musculoskeletal disorders in Gondar town.

Age, rest period taken, repetitive movement, reaching/ overstretching, organization concern for health and safety, and satisfaction were the work-related risk factors significantly associated with neck and upper limb MSDs.

Therefore, ergonomic, organizational, and personal measures, which focus on minimizing repetitive movement and awkward working position and facilitating rest break with exercise, are important to reduce neck and upper limb musculoskeletal disorders among hotel housekeepers.

\section{Abbreviations}

AOR: Adjusted odds ratio; BMI: Body mass index; Cl: Confidence interval; COR: Crude odds ratio; ETB: Ethiopian birr; MSDs: Musculoskeletal disorders; SPSS: Statistical Package for Social Science; UK: United Kingdom

\section{Acknowledgements}

We would like to express our gratitude to supervisors, data collectors, and the entire study participants for their full participation in the study.

\section{Funding}

There was no source of funding for this study.

\section{Availability of data and materials}

All data generated or analyzed during this study are included in this article. The data that support the findings of this study are also available from the corresponding author upon reasonable request.

\section{Authors' contributions}

SDW contributed to the study design, data collection, data analysis, interpretations of the results, and manuscript write-up. DHC and AD contributed to the data analysis, interpretations of the results, and manuscript writeup and review. All authors read and approved the final manuscript.

\section{Ethics approval and consent to participate}

Ethical clearance was obtained from the Ethical Review Committee of Institute of Public Health, College of Medicine and Health Sciences, University of Gondar. Permission letter was also obtained from each hotel manager. Those hotel housekeepers in Gondar town hotels, who were selected to participate, were informed about the purpose of the study, the importance of their participation and withdraw at any time. Verbal consent was obtained prior to data collection.

\section{Consent for publication}

Not applicable.

\section{Competing interests}

The authors declare that they have no competing interests.

\section{Publisher's Note}

Springer Nature remains neutral with regard to jurisdictional claims in published maps and institutional affiliations.
Received: 21 January 2019 Accepted: 9 April 2019

Published online: 03 May 2019

\section{References}

1. Meenaxi T, Sudha B. Causes of musculoskeletal disorder in textile industry. Int Res J Soc Sci. 2012;1:48-50.

2. Coyte PC, Asche CV, Croxford R, Chan B. The economic cost of musculoskeletal disorders in Canada. Arthritis Rheum. 1998;11:315-25.

3. Council NR. Musculoskeletal disorders and the workplace: low back and upper extremities: Washington (DC): National Academies Press; 2001.

4. Picavet $\mathrm{H}$, Schouten J. Musculoskeletal pain in the Netherlands: prevalences, consequences and risk groups, the DMC3-study. Pain. 2003;102:167-78.

5. Stock S, Baril R, Dion-Hubert C, Lapointe C, Paquette S, Sauvage J, Simoneau S, Vaillancourt C. Work related musculoskeletal disorders: guide and tools for modified work. Agence de développement de réseaux locaux de services de santé et de services sociaux de Montréal, Direction de santé publique; 2005.

6. Huisstede BM, Bierma-Zeinstra SM, Koes BW, Verhaar JA. Incidence and prevalence of upper-extremity musculoskeletal disorders. A systematic appraisal of the literature. BMC Musculoskelet Disord. 2006;7:7.

7. Podniece Z, Heuvel S, Blatter B. Work-related musculoskeletal disorders: prevention report; Luxembourg: European Agency for Safety and health at Work; 2008.

8. Deros BM, Daruis DD, Khamis NK, Mohamad D, Daud SFM, Amdan SM, Aziz RA, Jamal N. Prevalence of work related musculoskeletal disorders symptoms among construction workers: a case study in Malaysia. Iran J Public Health. 2014:43:53.

9. Health and safety executive: Work-related Musculoskeletal Disorder (WRMSDs) Statistics in Great Britain. 2016.

10. Health and Safety Authority: Guidance on the Prevention and Management of Musculoskeletal Disorders (MSDs) in the Workplace. 2013.

11. Council NR: Institute of Medicine. 2001. Musculoskeletal Disorders and the Workplace-Low Back and Upper Extremities. National Academy of Sciences Washington, DC: National Academy Press. (Ex 3-6).

12. BLM: Work-related upper-limb disorders: occupational disease guide 5. 2016

13. European Agency for Safety and Health at Work: E-fact 39 - Cleaners and musculoskeletal disorders. 2008. https://osha.europa.eu/en/tools-andpublications/publications/e-facts/efact39.

14. Bell AF, Steele JR. Risk of musculoskeletal injury among cleaners during vacuuming. Ergonomics. 2012:55:237-47.

15. Canadian Centre for Occupational Health and Safety: Hotel Housekeeping. 2016.

16. El Tayeb I, Ghareeb N, Zalat M. Prevalence of musculoskeletal problems among full time lady servants in Doqqi area, Cairo. Egypt J Occup Med. 2013;37:47-59.

17. Mammen R. Assessment of physical workload, ergonomic problems and prevalence of pain among low wage hotel housekeepers in Orlando; 2017.

18. Frumin E. Workload-related musculoskeletal disorders among hotel housekeepers: employer records reveal a growing national problem; 2006.

19. Mäkelä M, Heliövaara M, Sievers K, Knekt P, Maatela J, Aromaa A. Musculoskeletal disorders as determinants of disability in Finns aged 30 years or more. J Clin Epidemiol. 1993;46:549-59.

20. Picavet $\mathrm{H}$, Schouten J. Musculoskeletal pain in the Netherlands: prevalences, consequences and risk groups, the DMC 3-study. Pain. 2003;102:167-78.

21. Simoneau S, St-Vincent M, Chicoine D. Work-related musculoskeletal disorders (WMSDs)-a better understanding for more effective prevention. Québec: IRSST; 1996. p. 14.

22. Sim J, Lacey RJ, Lewis M. The impact of workplace risk factors on the occurrence of neck and upper limb pain: a general population study. BMC Public Health. 2006:6:234

23. Roquelaure $\mathrm{Y}, \mathrm{Ha}$ C, Rouillon C, Fouquet N, Leclerc A, Descatha A Touranchet A, Goldberg M, Imbernon E. Risk factors for upper-extremity musculoskeletal disorders in the working population. Arthritis Care Res. 2009:61:1425-34.

24. Pelissier C, Fontana L, Fort E, Agard JP, Couprie F, Delaygue B, Glerant V, Perrier C, Sellier B, Vohito M. Occupational risk factors for upper-limb and neck musculoskeletal disorder among health-care staff in nursing homes for the elderly in France. Ind Health. 2014:52:334-46.

25. Feng $B$, Liang $Q$, Wang $Y$, Andersen $L L$, Szeto $G$. Prevalence of work-related musculoskeletal symptoms of the neck and upper extremity among dentists in China. BMJ Open. 2014;4:e006451. 
26. Kumar R, Kumar S. Musculoskeletal risk factors in cleaning occupation-a literature review. Int J Ind Ergon. 2008;38:158-70.

27. Rathi M, Oza PA, Palekar T, Gazbare P, Khandare S. Effect of ergonomic advice on upper extremity work related musculoskeletal disorders in housekeepers. Int J Sci Res Educ. 2017;5:6419-24.

28. Nevala-Puranen N, Pakarinen K, Louhevaara V. Ergonomic intervention on neck, shoulder and arm symptoms of newspaper employees in work with visual display units. Int J Ind Ergon. 2003;31:1-10.

29. Holtermann A, Blangsted A, Christensen H, Hansen K, Søgaard K. What characterizes cleaners sustaining good musculoskeletal health after years with physically heavy work? Int Arch Occup Environ Health. 2009:82:1015.

30. Jørgensen MB, Faber A, Hansen JV, Holtermann A, Søgaard K. Effects on musculoskeletal pain, work ability and sickness absence in a 1-year randomised controlled trial among cleaners. BMC Public Health. 2011;11:840.

31. Nakamura K, Takachi R, Kitamura K, Saito T, Kobayashi R, Oshiki R, Watanabe Y, Kabasawa K, Takahashi A, Tsugane S. The Murakami cohort study of vitamin D for the prevention of musculoskeletal and other age-related diseases: a study protocol. Environ Health Prev Med. 2018;23:28.

32. Cagnie B, De Meulemeester K, Saeys L, Danneels L, Vandenbulcke L, Castelein B. The impact of different lenses on visual and musculoskeletal complaints in VDU workers with work-related neck complaints: a randomized controlled trial. Environ Health Prev Med. 2017:22:8

33. Kuorinka I, Jonsson B, Kilbom A, Vinterberg H, Biering-Sørensen F, Andersson G, Jørgensen K. Standardised Nordic questionnaires for the analysis of musculoskeletal symptoms. Appl Ergon. 1987;18:233-7.

34. Macdonald S, Maclntyre P. The generic job satisfaction scale: scale development and its correlates. Empl Assist Q. 1997;13:1-16.

35. Habib R, El Zein K, Hojeij S. Hard work at home: musculoskeletal pain among female homemakers. Ergonomics. 2012;55:201-11.

36. Woods V, Buckle P. Musculoskeletal ill health amongst cleaners and recommendations for work organisational change. Int J Ind Ergon. 2006;36: $61-72$.

37. Kalra S, Bhatnagar B. Prevalence of musculoskeletal disorder among housewives; 2017

38. De Zwart B, Frings-Dresen M, Kilbom Å. Gender differences in upper extremity musculoskeletal complaints in the working population. Int Arch Occup Environ Health. 2000;74:21-30.

39. Lee JW, Lee JJ, Mun HJ, Lee K-J, Kim JJ. The relationship between musculoskeletal symptoms and work-related risk factors in hotel workers. Ann Occup Environ Med. 2013;25:20.

40. Cavallari JM, Ahuja M, Dugan AG, Meyer JD, Simcox N, Wakai S, Garza JL. Differences in the prevalence of musculoskeletal symptoms among female and male custodians. Am J Ind Med. 2016;59:841-52.

41. European Agency for Safety and Health at Work: Factsheet 72 - Workrelated neck and upper limb disorders. 2007. https://osha.europa.eu/en/ tools-and-publications/publications/factsheets/72.

42. Werner RA, Franzblau A, Gell N, Ulin SS, Armstrong TJ. Predictors of upper extremity discomfort: a longitudinal study of industrial and clerical workers. J Occup Rehabil. 2005;15:27-35

43. Calvet B, Riel J, Couture V, Messing K. Work organisation and gender among hospital cleaners in Quebec after the merger of 'light'and 'heavy'work classifications. Ergonomics. 2012;55:160-72.

44. Lundberg U. Arbetsmiljöns betydelse för ryggproblem: En systematisk litteraturöversikt. In: Statens beredning för medicinsk utvärdering (SBU); 2014

Ready to submit your research? Choose BMC and benefit from:

- fast, convenient online submission

- thorough peer review by experienced researchers in your field

- rapid publication on acceptance

- support for research data, including large and complex data types

- gold Open Access which fosters wider collaboration and increased citations

- maximum visibility for your research: over $100 \mathrm{M}$ website views per year

At $\mathrm{BMC}$, research is always in progress.

Learn more biomedcentral.com/submissions 